\title{
Localization of Neurons Afferent to the Optic Tectum in Longnose Gars
}

\author{
R. GLENN NORTHCUTT \\ Division of Biological Sciences, University of Míchigan, Ann Arbor, Michigan 48109
}

\begin{abstract}
Afferent pathways to the optic tectum in the longnose gar were determined by unilateral tectal injections of HRP. Retrogradely labeled cells were observed in the ipsilateral caudal portion of the rostral entopeduncular nucleus and bilaterally in the rostral half of the lateral zone of area dorsalis of the telencephalon. The following diencephalic cell groups were also labeled following tectal injections: the ipsilateral anterior, ventrolateral, and ventromedial thalamic nuclei, the periventricular pretectal nucleus, and the central pretectal nucleus (bilaterally); the ventromedial thalamic and central pretectal nuclei revealed the largest number of labeled cells. At midbrain levels, retrogradely labeled cells were seen in the ipsilateral torus longitudinalis, nucleus isthmi, and accessory optic nucleus; cells were labeled bilaterally in the torus semicircularis and a rostral tegmental nucleus. Only a few cells were labeled in the contralateral optic tectum, suggesting that few of the fibers of the intertectal commissure are actually commissural to the tectum. At hindbrain levels, retrogradely labeled cells were seen bilaterally in the locus coeruleus, the superior, medial, and inferior reticular formations, the eurydendroid cells of the cerebellum, and the nucleus of the descending trigeminal tract; the contralateral dorsal funicular nucleus also exhibited labeling. Clearly, the tectum in gars receives a substantial number of nonvisual afferents from all major brain areas, most of which have been reported in other vertebrates. The functional significance of these afferent sources and their probable homologues in other vertebrate groups are discussed.
\end{abstract}

Ray-finned fishes constitute the largest radiation of living vertebrates: some 20,000 species, representing several grades of organization. Teleosts comprise the most advanced grade and the largest number of species, whereas the more primitive grades (polypteriforms, chondrosteans, and holosteans) are represented by only a few extant species. Gars are living holosteans whose brain organization is more simple than that of teleosts and may serve as a model of the primitive ray-finned stock. A better understanding of brain organization in gars should help to identify evolutionary trends within ray-finned fishes and how this radiation differs from land vertebrates.

Gars, like most teleosts, are highly visual predators with large, well-laminated optic tecta. The retinal projections and tectal efferents in gars have been examined experimentally (Northcutt and Butler, '76, '80); however, nonvisual inputs to the optic tectum have not been determined.

Horseradish peroxidase (HRP) injections into the optic tectum of gars were used to identify the sources of tectal afferents and reveal visually related brain regions. We can now compare these regions to those in teleosts, for which experimental information is now available (Grover and Sharma, '81), and to other vertebrates.

\section{MATERIALS AND METHODS}

Ten juvenile specimens (21-27 cm total length) of Lepisosteus osseus ( $=$ Lepidosteus osseus) received unilateral tectal injections of HRP (Sigma VI). Animals were anesthetized by immersion in $0.1 \%$ methanesulfonate solution; the dermal bone overlying the neurocranium and optic tectum was removed by dental drill, and a window was cut through the cartilaginous neuracranium overlying the optic tectum. Volumes of $100-300 \mathrm{nl}$ of $20 \%$ HRP solution were delivered by micropipette pressure injections (three cases), or the tectum was inoculated with HRP paste on the tip of a " 00 " insect pin (seven cases). The surface of the tectum was then flushed with saline solution to remove

Accepted October 22, 1981. 
any excess HRP and the wound closed with Gelfoam and dental zinc cement.

Following survival times of $4-16$ days at $27^{\circ} \mathrm{C}$, the animals were reanesthetized and perfused transcardially with cold $0.1 \mathrm{M}$ phosphate buffer ( $\mathrm{pH} 7.4$ ), followed by $2 \%$ glutaraldehyde in $0.1 \mathrm{M}$ phosphate buffer. The brains were removed and allowed to fix for 1 additional hour in a solution of $2 \%$ glutaraldehyde in $0.1 \mathrm{M}$ phosphate buffer with $10 \%$ sucrose added. The brains were then washed in $10 \%$ sucrose phosphate buffer; the meninges were removed; and the brains were embedded in gelatin blocks and fixed for an additional 4 hours in $2 \%$ glutaraldehyde in sucrose buffer. Thirty-five-micron transverse sections were cut on a sled microtome with a freezing attachment, collected in phosphate buffer, and stored at $7^{\circ} \mathrm{C}$.

The sections were reacted with o-dianisidine, following the method of Coleman et al. (76), or with tetramethylbenzidine (TMB), following the method of Mesulam ('79), mounted on subbed slides using alcoholic gelatin solution, and air dried. Most sections were counterstained with $1 \%$ neutral red; an occasional series was mounted directly out of phosphate buffer, air dried, and transferred directly to xylene, without counterstaining or dehydration through graded alcohols, in order to check for potential reduction of reaction products.

\section{RESULTS}

All survival times yielded positive results, although survival times of 8 days or longer revealed far more retrogradely labeled cells. The TMB method of Mesulam (79) was more sensitive and provided more complete filling of cells; frequently very fine second- and third-order dendritic processes were revealed (Fig. 6). Both anterograde and retrograde labeling were observed, and the tectal efferents were as well defined by the HRP methods as those revealed by the Fink-Heimer method in an earlier study of tectal efferents in gars (Northcutt and Butler, '80).

Introduction of HRP by the inoculation method did not produce larger injection sites within the tectum than did the pressure injections and resulted in more densely filled cells as well as more consistent results from case to case. In many of the cases, HRP was taken up by the ependymal cells immediately beneath or adjacent to the injection sites. However, these cases did not reveal additional sources of retrogradely labeled neurons when compared to cases that did not involve ependymal uptake.

Two different types of retrograde labeling were observed in the TMB preparations. More frequently, the labeled cells exhibited complete filling of the cell bodies; fine dendritic processes were revealed, and a Golgi-like picture was evidenced. Less frequently, the cell bodies contained distinct, dense granules of reaction product, rather than complete filling, a type of labeling seen most commonly among cells of the lateral zone of area dorsalis of the telencephalon, eurydendroid cells of the cerebellum, and inferior raphe nucleus. This second type of reaction is, however, interpreted as retrograde labeling by HRP, rather than the reaction of other endogenous peroxidases, or the presence of normally occurring pigment granules. Horseradish peroxidase injections into other brain regions do not result in granules in these cells (unpublished observations), nor are granules seen in these cells in nonexperimental material.

$\begin{array}{ll}\text { A } & \text { Anterior thalamic nucleus } \\ \text { AO } & \text { Accessory optic nucleus } \\ \text { AU } & \text { Auricle of the cerebellum } \\ \text { C } & \text { Central nucleus of torus semicircularis } \\ \text { CC } & \text { Cerebellar crest } \\ \text { CO } & \text { Corpus cerebelli } \\ \text { CP } & \text { Central posterior thalamic nucleus } \\ \text { DF } & \text { Nucleus diffusus of the inferior lobe } \\ \text { DI } & \text { Lateral zone of area dorsalis } \\ \text { Dm } & \text { Medial zone of area dorsalis } \\ \text { DN } & \text { Descending octaval nucleus } \\ \text { DP } & \text { Dorsal posterior thalamic nucleus } \\ \text { DV } & \text { Descending trigeminal nucleus and tract } \\ \text { E } & \text { Rostral entopeduncular nucleus } \\ \text { EN } & \text { Eurydendroid neurons of cerebellum } \\ \text { FN } & \text { Dorsal funicular nucleus } \\ \text { FR } & \text { Fasciculus retroflexus } \\ \text { G } & \text { Glomerular complex } \\ \text { H } & \text { Habenular nuclei } \\ \text { HY } & \text { Hypothalamus } \\ \text { I } & \text { Intermediate thalamic nucleus } \\ \text { IL } & \text { Inferior lobe } \\ \text { IP } & \text { Interpeduncular nucleus } \\ \text { IR } & \text { Inferior raphe nucleus } \\ \text { IRF } & \text { Inferior reticular formation } \\ \text { L } & \text { Laminar nucleus of torus semicircularis } \\ \text { LC } & \text { Locus coeruleus } \\ \text { MN } & \text { Magnocellular octaval nucleus } \\ \text { MON } & \text { Medial octavolateralis nucleus } \\ \text { MRF } & \text { Medial reticular formation } \\ \text { NI } & \text { Nucleus isthmi } \\ \text { NS } & \text { Nucleus solitarius } \\ \text { nMLF } & \text { Nucleus of the medial longitudinal fasciculus } \\ \text { OB } & \text { Olfactory bulb } \\ \text { OC } & \text { Optic chiasm } \\ & \\ & \end{array}$




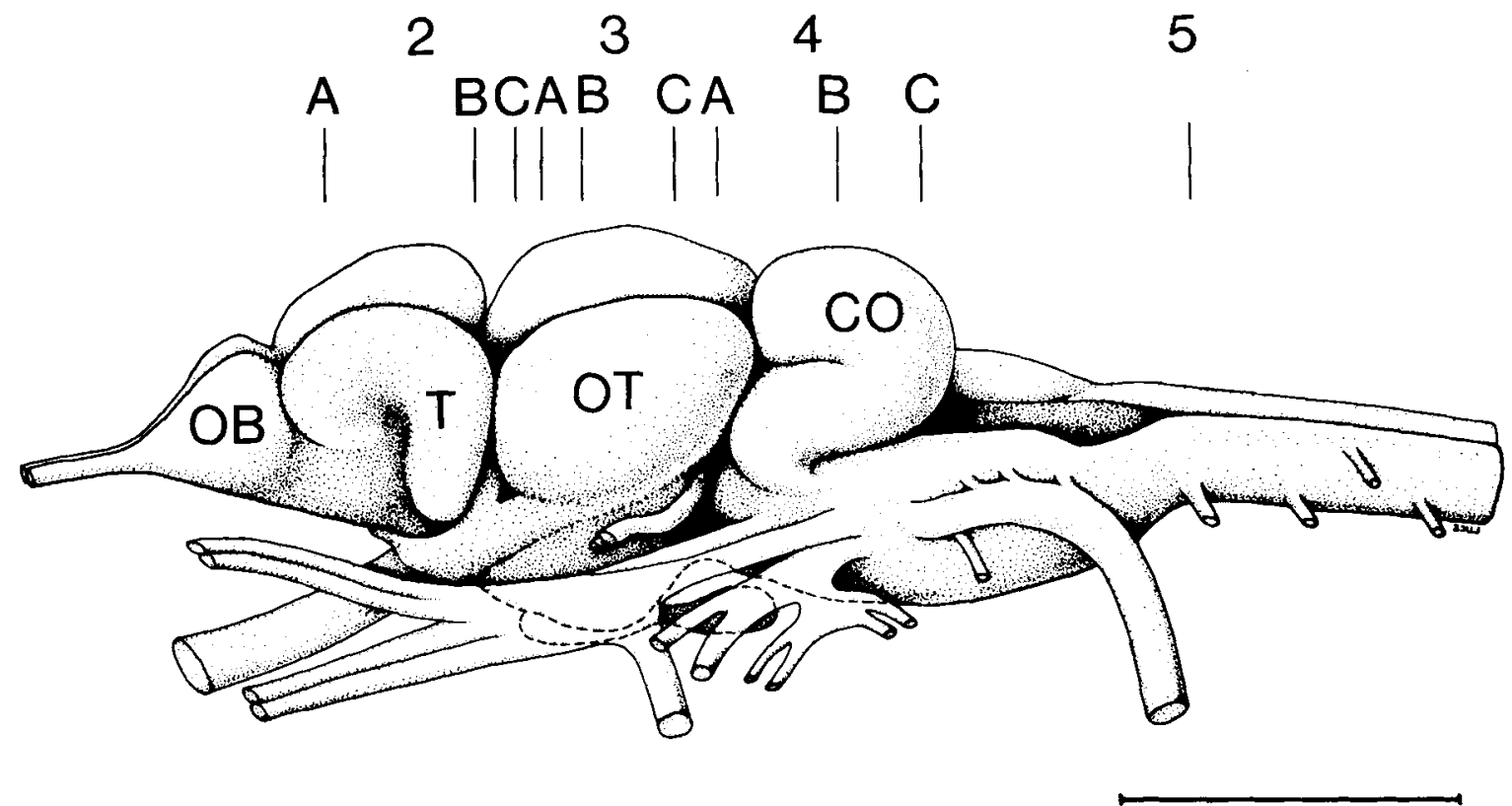

Fig. 1. Dorsolateral view of the brain of Lepisosteus osseus. Numbered lines indicate the levels of the transverse sections in Figures 2-5. Bar scale equals $5 \mathrm{~mm}$.

Case 5 ( 8 days survival time) was typical of the more successful cases and is charted in Figures $2-5$. The levels of the transverse sections are illustrated in Figure 1. The nomenclature is that introduced in earlier reports (Northcutt and Butler, '76, '80; Northcutt and Braford, '80; Braford and Northcutt, '81).

Unilateral tectal injections resulted in retrogradely labeled cells in all major brain divisions (Figs. 2-5); their sites are discussed below according to brain region.

\section{Forebrain}

Retrograde label was seen bilaterally in the larger cells occupying the center of the rostral half of the lateral zone of area dorsalis (Dl) of the telencephalon (Fig. 2A). Slightly more labeled cells were observed contralateral than ipsilateral to the injected tectum. None of the labeled cells in $\mathrm{Dl}$ revealed the complete Golgi-like filling seen in many areas, but dense granular deposits in their cytoplasm were consistent in those cases that received tectal inoculation of HRP. Cells so labeled were not observed following pressure injections of HRP into the tectum or in control cases.

Only one additional group was labeled in the telencephalon following tectal injections of HRP (Fig. 2B): a few cells in the caudal portion of the ipsilateral rostral entopeduncular nucleus of the telencephalon medium. These cells exhibited the typical Golgi-like filling observed in most retrogradely labeled cells.

Retrogradely filled cells were observed in several nuclei in the thalamus and pretectum (Figs. 2B, 3A). In the thalamus, the largest population of labeled neurons was restricted to the ipsilateral ventromedial thalamic nucleus (VM, Fig. 2B,C); more sparse labeling occurred among cells of the ipsilateral anterior (Fig. 2C) and ventrolateral (Fig. 2C) thalamic nuclei. All three of these nuclei also receive a direct retinal input (Northcutt and Butler, '76) as well as projections from the optic tectum (Northcutt and Butler, ' 80 ). In several cases, an occasional labeled cell was also found in the ipsilateral dorsal posterior thalamic nucleus (Fig. 3A). However, the contribution of this nucleus to a tectal projection appears to be extremely small compared to that of other thalamic nuclei.

The pretectum of gars consists of superficial (PSP, Fig. 2C), central (PC, Fig. 3A), and periventricular (PP, Fig. 3A) pretectal nuclei (Northcutt and Butler, '76). A large number of retrogradely labeled neurons were seen bilaterally in the central pretectal nucleus (Fig. 3A) and somewhat fewer in the ipsilateral periventricular pretectal nucleus (Fig. 3A). Thus two of the three pretectal nuclei appear to project to the optic tectum. All three pretectal nuclei also receive direct retinal (Northcutt and Butler, '76) and tectal (Northcutt and Butler, '80) inputs.

Labeled neurons were also observed in the ipsilateral accessory optic nucleus (AO, Fig. 3A,B). It is not clear from its topographical position whether this nucleus is a diencephalic or mesencephalic nucleus, but it also receives direct retinal and tectal inputs (Northcutt and Butler, '76, '80).

\section{Midbrain}

Large numbers of retrogradely labeled cells were seen in the ipsilateral torus longitudinalis (TL, Fig. 3B,C) following tectal injections of HRP. The toral cells were densely filled, and labeling was coextensive rostrocaudally with the core of the HRP injection sites. Thus it appears that the cells of the torus longitudinalis project topographically upon the ipsilateral tectum.

Unilateral tectal injections of HRP revealed large numbers of filled fibers coursing through the deep white zone of the optic tectum and decussating to the contralateral 

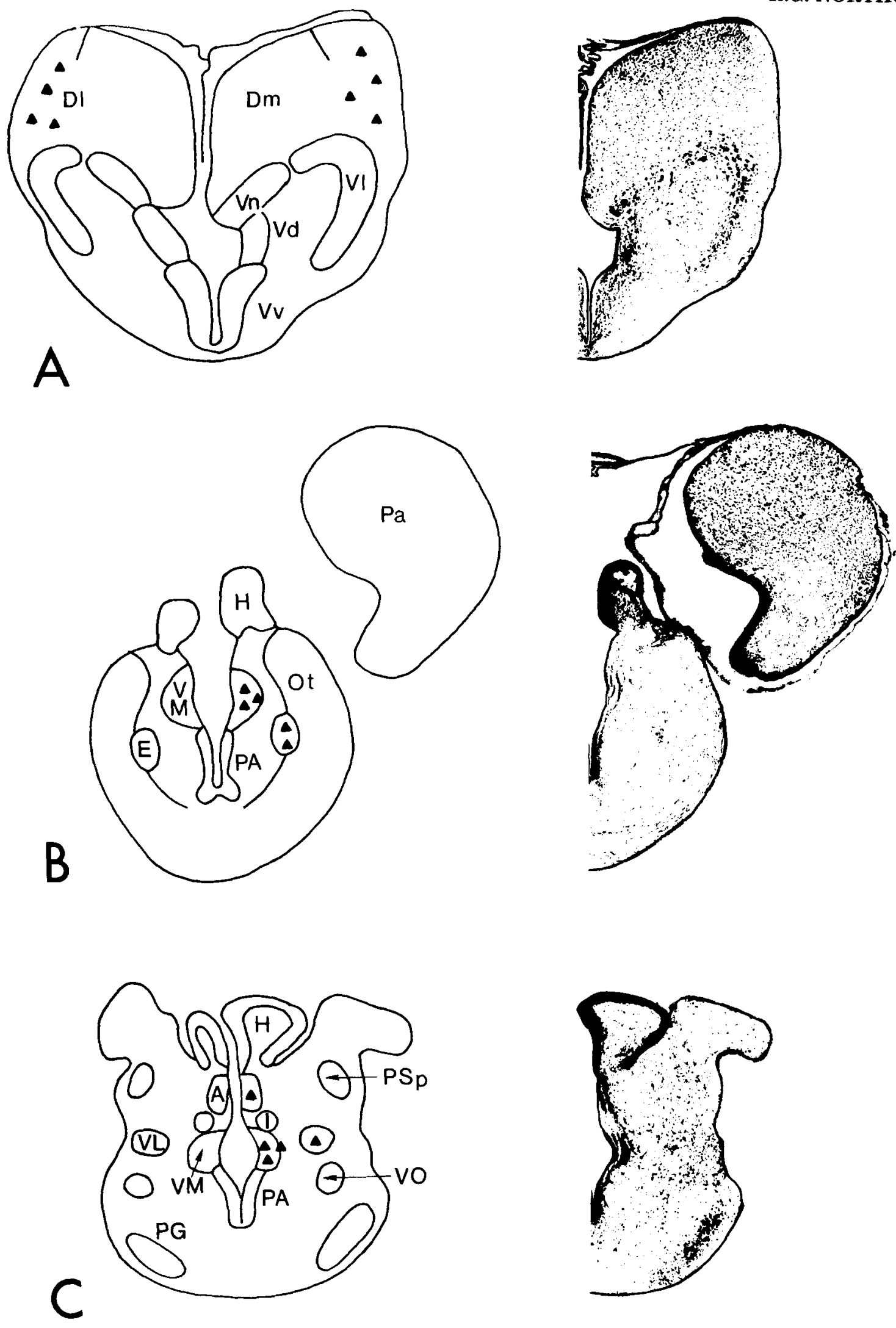

Fig. 2. Transverse sections through the rostral telencephalon (A) and diencephalon ( $\mathrm{B}$ and $\mathrm{C}$ ) of the longnose gar illustrating the position of retrogradely labeled neurons (triangles) following a unilateral HRP injec-

tion into the optic tectum. In this and Figures $3-5$, the injected side of the brain is illustrated as the right half of the charting. Bar scale in Figures $2-5$ equals $1 \mathrm{~mm}$ 

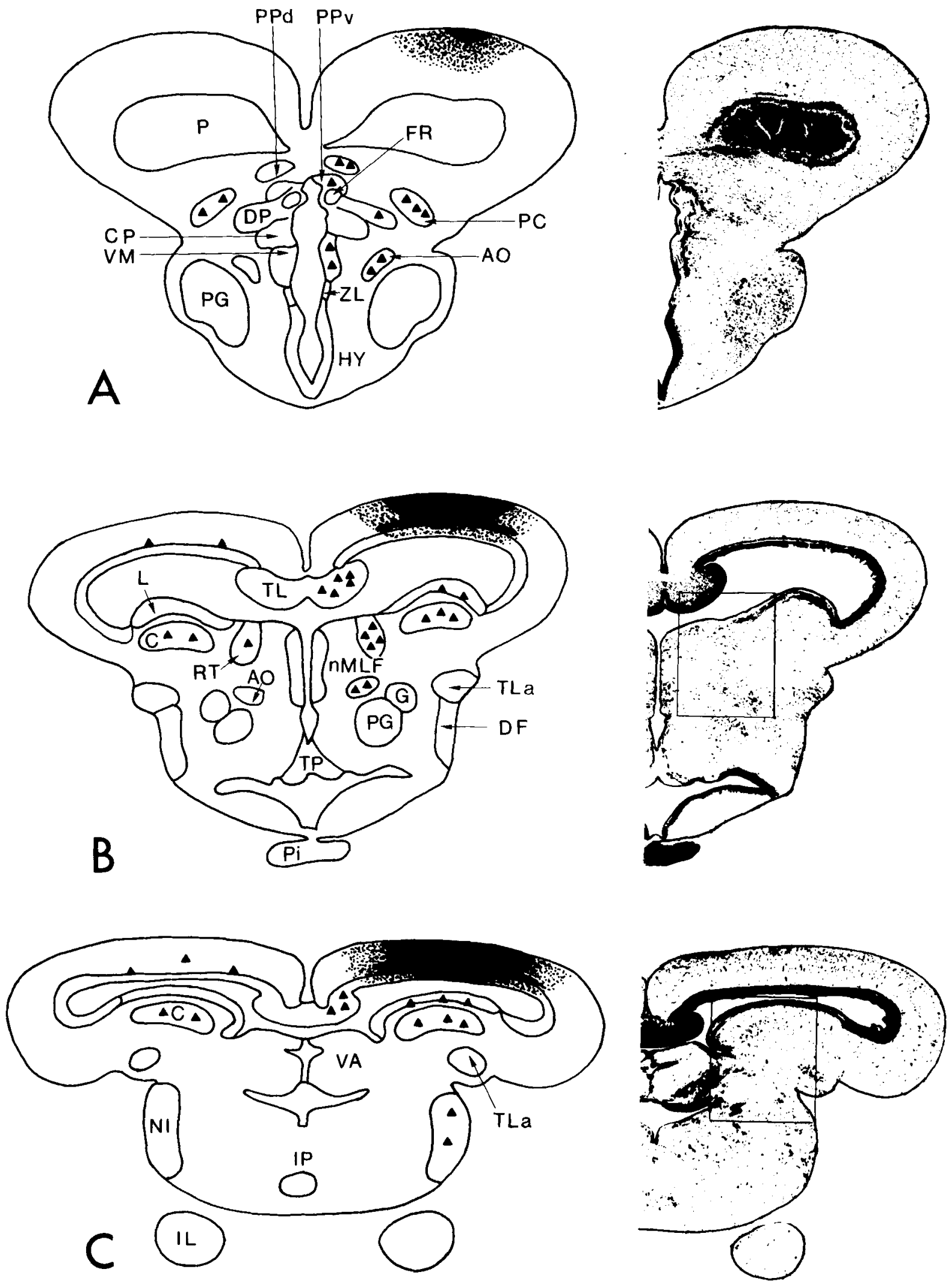

Fig. 3. Transverse sections through rostral (A) to caudal (C) midbrain levels of the longnose gar illustrating the position of retrogradely labeled neurons (triangles) following a unilateral HRP injection into the optic tectum. Position and extent of the core and annulus of the injection are indicated by solid black and stippled areas, respectively. Rectangles in B and $\mathrm{C}$ indicate the orientation and extent of photographed field of Figure $6 \mathrm{~B}$ and $\mathrm{C}$, respectively. 
tectum via the intertectal commissure. Although some of these fibers exit from the ventrolateral edge of the tectum and can be traced into the contralateral torus semicircularis, the bulk of the labeled fibers are confined to the medial half of the contralateral tectum. Considering the large number of labeled fibers crossing the intertectal commissure, there were suprisingly few retrogradely labeled cells in the contralateral tectum. In any given transverse section, it was rare to observe more than two or three clearly labeled neurons, even after large injections that involved the deep white zone of the injected tectum. Two classes of labeled neurons were observed in the contralateral tectum following such injections: pyriform cells of the periventricular gray zone, and fusiform neurons of the central zone. The pyriform cells constituted the bulk of the labeled neurons, and fusiform cells were seen only rarely.

In contrast, large numbers of cells were labeled bilaterally in the torus semicircularis (Figs. 3B,C, 6C) following tectal injections. The torus semicircularis of gars is divided into ventricular laminar (L, Fig. 3B) and central (C, Fig. 3B) nuclei. Whereas the central nucleus was labeled bilaterally, labeling was observed only in the ipsilateral laminar nucleus. The large number of bilaterally labeled cells in the torus semicircularis-compared to the small number of labeled neurons in the contralateral tectumsuggests that many of the "intertectal fibers" located in the intertectal commissure may, in fact, be commissural or efferents of the torus semicircularis instead.

Two additional midbrain cell groups reveal retrogradely labeled cells following tectal injections: a rostral tegmental nucleus (RT, Fig. 3B) and a caudal tegmental nucleus (NI, Fig. 3C) that may be homologous to nucleus isthmi in other vertebrates.

In the rostral tegmentum, lateral to the nucleus of the MLF, there is a distinct finger-shaped group of scattered medium-sized fusiform neurons that $I$ have termed the rostral tegmental nucleus (RT, Fig. 3B). Large tectal injections resulted in essentially complete retrograde labeling of cells in the ipsilateral nucleus, as well as a few labeled cells in the contralateral nucleus. This rostral tegmental nucleus was clearly the most heavily labeled cell group in the tegmentum.

More caudally, a migrated group of medium-sized neurons (NI, Fig. 3C) occurs on the lateral edge of the tegmentum or isthmus, scattered among the exiting, uncrossed tectobulbar fibers. Many of the cells of the ipsilateral nucleus isthmi appeared to be labeled by tectal injections, but this was difficult to establish due to the massive labeling of the descending tectal efferents.

\section{Hindbrain}

A small group of large spindle-shaped neurons, lying lateral to the sulcus limitans at the level of the caudal isthmus (Fig. 4A), is bilaterally labeled following tectal injections. These are probably cells of the locus coeruleus, as scattered cells in this region in gars contain catecholamines (Parent and Northcutt, '81) and have also been demonstrated to project to the telencephalon in other fishes (Echteler and Saidel, '81; Northcutt, '81).

The brainstem reticular formation in gars, as in other fishes, consists of a column of scattered, large neurons that form three distinct rostrocaudal aggregates: the superior, medial, and inferior reticular formations (Fig. 4). Following tectal injections, retrogradely labeled cells were seen bilaterally in all three reticular aggregates, but counts of the filled cells (a total of 74 among three different cases) revealed no obvious laterality.

A median brainstem reticular formation, consisting of superior (Fig. 4A) and inferior (Fig. 4C) raphe nuclei, also occurs in gars. The cells of the inferior raphe (Fig. 4C) were retrogradely labeled following most tectal injections. Labeling of the inferior raphe neurons was dense, as in most labeled cell groups, and granular filling of the cytoplasm was frequently seen in these cells as well.

The medial octavolateralis nucleus of gars is a nuclear aggregate of several cell types, including large Purkinjelike neurons whose dorsally directed dendrites enter an overlying molecular layer termed the cerebellar crest. In fishes, the medial octavolateralis nucleus is the primary target of entering mechanoreceptive lateral line information (McCormick, '78, '81; Bodznick and Northcutt, '80). Following tectal injections, labeled Purkinje-like cells (Figs. 4A, 6A) were frequently seen in the contralateral medial nucleus. An occasional labeled neuron was also seen in the contralateral descending octaval nucleus, but these cells were rare.

In most vertebrates, few of the cerebellar Purkinje cells send their axons outside of the cerebellum; instead, they terminate on deep cerebellar nuclei which, in turn, give rise to most extrinsic cerebellar efferents. Teleosts do not appear to possess distinct, deep cerebellar nuclei. In these fishes, the homologous cells (eurydendroid neurons) are scattered as distinct groups of cells closely associated or interdigitated with the cerebellar cell layers (Finger, '78a). In gars, one such group lies embedded along the medial edge of the corpus cerebelli; these cells are bilaterally labeled following unilateral tectal injections (Fig. 4B), with more labeled cells contralateral to the injection. None of these cells revealed Golgi-like filling but were densely filled with granular reaction product following tectal injections. Projection of "cerebellar cells" to the contralateral tectum in gars has been confirmed by autoradiography (unpublished observations), and a similar pathway has been reported in teleosts (Finger, '78a).

Bilateral labeling of neurons in the nucleus of the descending trigeminal tract (Fig. 4B,C), and contralateral labeling of the dorsal funicular nucleus (Fig. 5) was also observed following unilateral tectal injections. Labeled cells in the nucleus of the descending trigeminal tract were sparse and scattered along the medial edge of the tract. Labeled cells were extremely dense in the contralateral dorsal funicular nucleus, many with Golgi-like profiles.

Occasionally, lightly labeled cells were observed bilaterally in the dorsal horn of the cervical spinal cord; however, these cells were observed only after the largest tectal injections, and labeling may have resulted from ventricular spread of the HRP. For this reason, other experimental methods must be applied to determine whether gars possess spinotectal pathways.

\section{DISCUSSION}

The cells of origin for the afferent pathways to the tectum in gars, as revealed in this study, are summarized in Figure 7. These data will now be compared with those for other vertebrates and discussed in terms of the possible types of afferent information reaching the tectum.

\section{Telencephalic projections}

Two widely separated telencephalic cell groups project to the optic tectum in gars: large cells in the core of the 

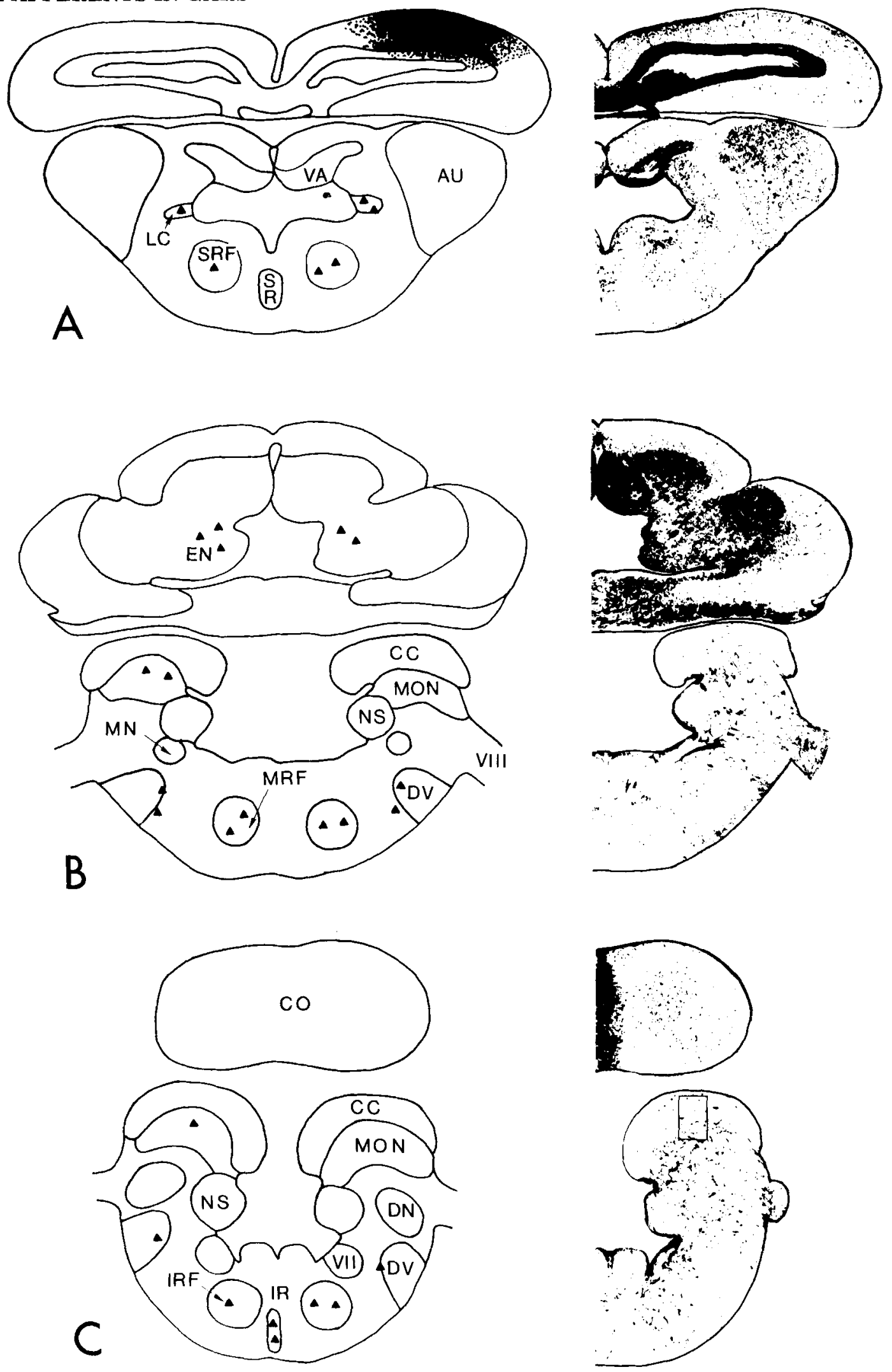

Fig. 4. Transverse sections through caudal tectal (A) and medullar (B and C) levels of the longnose gar. Rectangle in $\mathrm{C}$ indicates orientation and extent of photographed field of Figure $6 \mathrm{~A}$. 

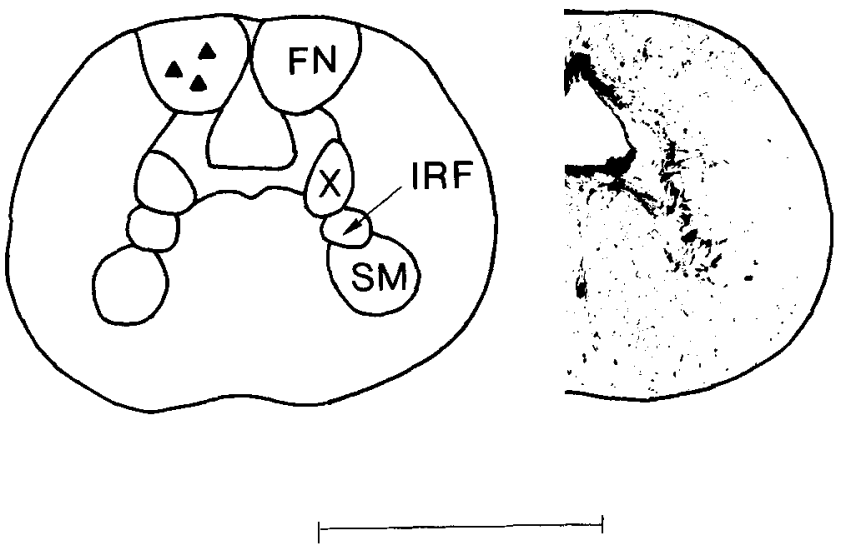

Fig. 5. Transverse section through the obex region of the longnose gar.

rostral half of the lateral zone of area dorsalis and cells located in the caudal portion of the rostral entopeduncular nucleus (Figs. 2A,B, 7). In teleosts, the central zone of area dorsalis $(\mathrm{Dc})$ is positioned similarly to the former and projects to the optic tectum (Ito and Kishida, '77; Bass, '79; Grover and Sharma, '81). Gars do not possess a distinct Dc complex, but the more centrally located cells of area dorsalis have been homologized to the Dc cells of teleosts on the basis of topological and histochemical similarities (Northcutt and Braford, '80). The projection of these cells to the optic tectum in gars reinforces these earlier observations. However, the lateral zone appears to project bilaterally in gars, whereas only ipsilateral projections to the tectum in teleosts were reported in two of the earlier studies (Ito and Kishida, '77; Bass, '79). Grover and Sharma ('81) did not comment on the laterality of the retrogradely labeled cells of Dc in goldfish. The apparent difference in laterality between gars and teleosts may characterize different grades of ray-finned fishes or may only reflect species variation. Additional species must be examined before phylogenetic trends can be analyzed.

In gars, a few caudally located cells in the rostral entopeduncular nucleus project to the ipsilateral optic tectum (Figs. 2B, 7). Entopeduncular projections to the optic tectum were not reported in goldfish by Grover and Sharma ('81); however, tectal projections from a similarly located, similarly named nucleus in amphibians are known (Wilczynski, '78). In amphibians, this is the only telencephalic nucleus that projects to the tectum, and further experimental studies may reveal this pathway to be widely distributed among anamniotes. In gars, the rostral entopeduncular nucleus also receives a bilateral input from the tectum (Northcutt and Butler, ' 80 ), and fibers of the optic tract pass through this nucleus in route to form the marginal optic tract (Northcutt and Butler,'76). Echteler and Saidel ('81) also reported entopedunuclar projections to telencephalic areas in the goldfish. At present, it is not clear whether the entopeduncular nucleus in teleosts is homologous to the larger complex in gars (Northcutt and Braford, ' 80 ), but these results suggest that the entopeduncular complex in ray-finned fishes is involved in visual processing and may possess widely spread efferents.

\section{Thalamic projections}

Three rostral thalamic cell groups give rise to projections to the ipsilateral optic tectum in gars: anterior, ventrolateral, and ventromedial thalamic nuclei (Figs. 2C, 7). In gars, all three rostral thalamic nuclei receive direct retinal and tectal projections (Northcutt and Butler, '76, '80). The same three thalamic nuclei can be recognized in teleosts (Braford and Northcutt, ' 81 ) but have traditionally been grouped under the terms nucleus dorsolateralis and dorsomedialis (Schnitzlein, '62). Grover and Sharma ('81), using the more traditional names for these nuclei, reported similar projections to the tectum in goldfish. The anterior thalamic nucleus is believed to be a dorsal thalamic nucleus, whereas the ventrolateral and ventromedial thalamic nuclei are assigned to the ventral thalamus (Braford and Northcutt, '81). The anterior thalamic nucleus also projects to the telencephalon in other ray-finned fishes (Echteler and Saidel, '81; Northcutt, '81). In amphibians, a similarly located nucleus also receives direct retinal projections (Scalia and Gregory, '70; Fite et al., '77) and projects bilaterally to the medial pallium (Ronan and Northcutt, '79) and ipsilaterally to the optic tectum (Neary and Wilczynksi, '80).

Of the three rostral thalamic nuclei, the ventromedial thalamic nucleus contains the largest number of retrogradely filled neurons following tectal injections and thus appears to give rise to the largest tectal projection. The ventromedial thalamic nucleus is also the major thalamic target of the ascending cerebellar peduncle (unpublished observations) and is thus involved as a relay nucleus linking the cerebellum and optic tectum, in addition to receiving retinal and tectal inputs. In amphibians, a similarly named and positioned nucleus projects to the tectum (Neary and Wilczynksi, '80), but amphibians have not been experimentally examined for possible cerebellar inputs to the ventromedial thalamic nucleus.

In most vertebrates experimentally examined to date, the rostral ventral thalamus contains a lateral complex that receives retinal and tectal input and projects, in part, to the optic tectum. In nonmammalian vertebrates, this complex has many names (ventrolateral thalamic nucleus in gars, lateral geniculate body and ventrolateral nucleus in amphibians, pars ventralis of the lateral geniculate nucleus and ventrolateral nucleus in reptiles, lateral geniculate nucleus in birds), but all of these nuclei are likely homologous to the ventral lateral geniculate nucleus of mammals, as indicated by the experimentally determined efferents for this complex among vertebrates (amphibians: Trachtenberg and Ingle, '74; Neary and Wilczynski, '80; reptiles: Gruberg et al., '79; birds: Crossland and Uchwat, '79; mammals: Grofová et al., '78).

One additional thalamic nucleus, the dorsal posterior thalamic nucleus, revealed occasional but dense labeling of a few cells in several of the gar cases (Fig. 3A). This nucleus is a major target of ascending tectal efferents in gars, but it does not receive direct retinal input (Northcutt and Butler, '76, '80) and is believed to be a dorsal thalamic nucleus, on the basis of its topographical position in the diencephalon (Braford and Northcutt, '81). The dorsal posterior thalamic nucleus was therefore proposed as a homologue of nucleus rotundus in amniotes (Northcutt and Butler, '80; Braford and Northcutt, '81), a relationship further indicated by its projection to the telencephalon in polypteriform (Northcutt, '81) and teleost (Echteler and Saidel, '81) fishes. 

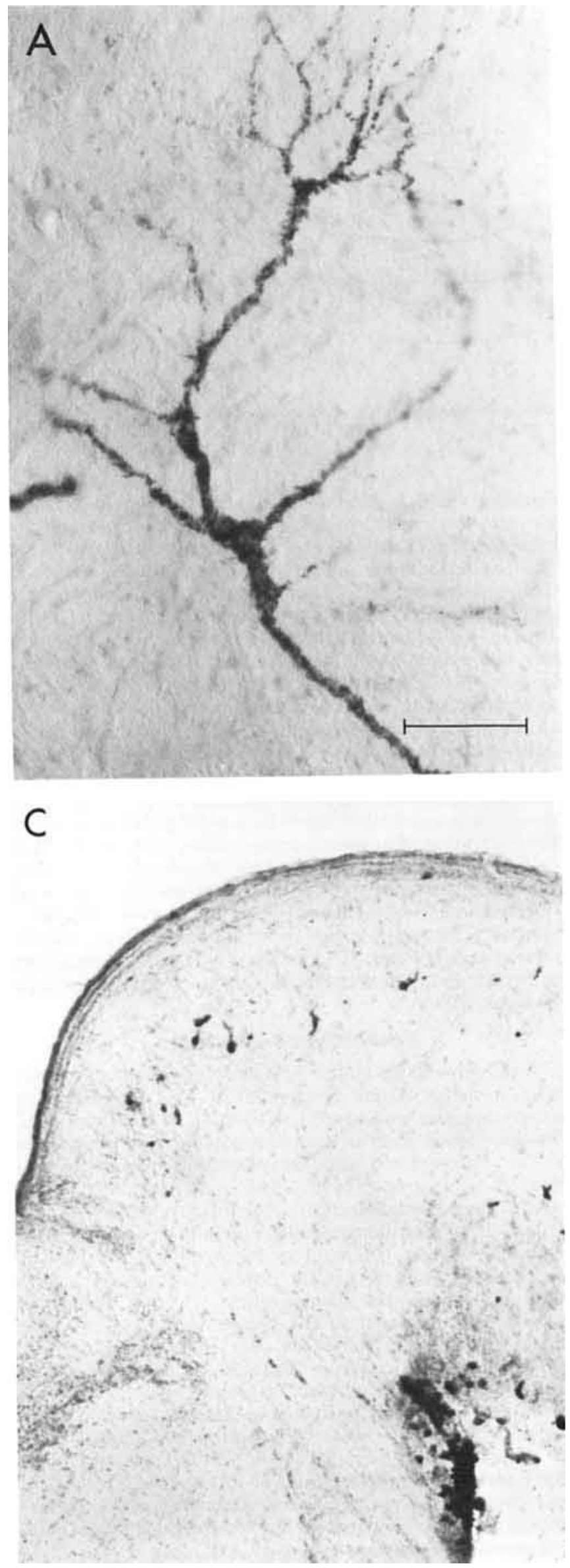

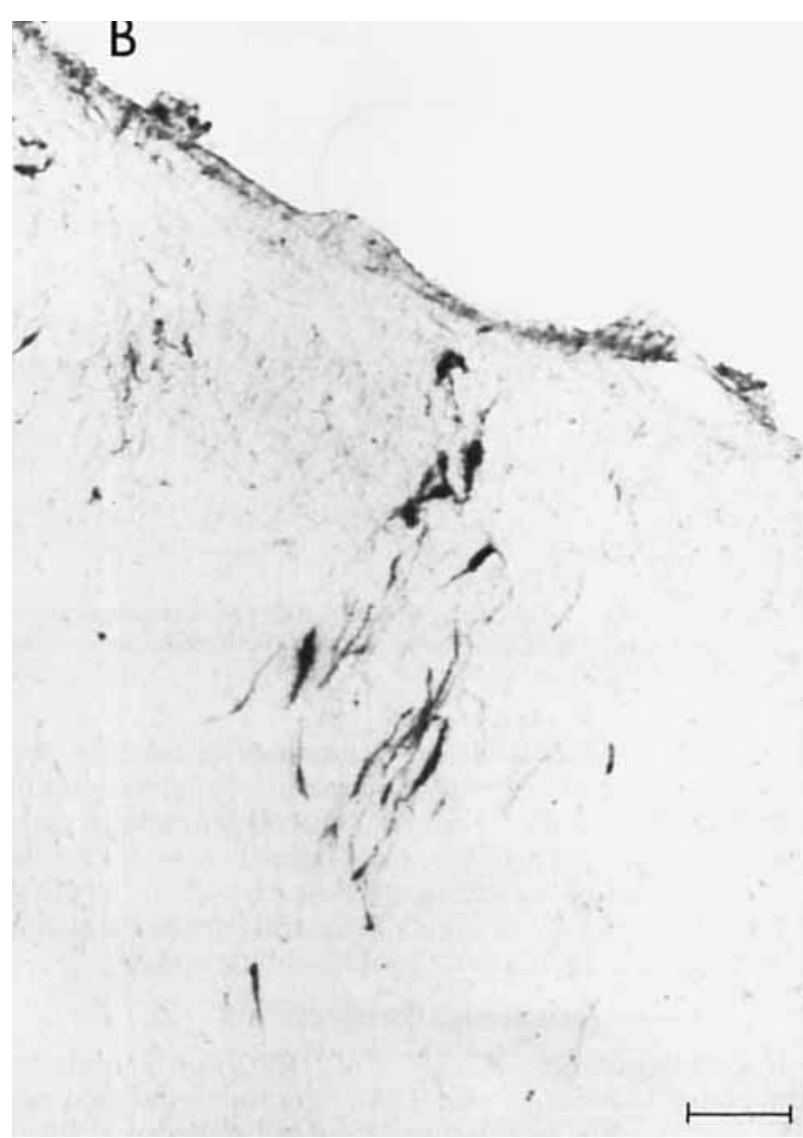

Fig. 6. Brightfield photomicrographs of neurons illustrating transport of HRP following a unilateral injection of the optic tectum. A. Purkinjelike neuron of the contralateral medial actavolateralis nucleus. B. Ipsilateral rostral tegmental nucleus. $C$. Contralateral central nucleus of the torus semicircularis. Bar scales equal $50 \mu \mathrm{m}$ (A) and $100 \mu \mathrm{m}$ (B and C).

\section{Pretectal projections}

The pretectum in gars projects extensively to the optic tectum (Figs. 3A, 7). Two of the three pretectal nuclei supply afferents to the tectum: The periventricular pretectal nucleus projects to the ipsilateral tectum, whereas the central pretectal nucleus projects bilaterally to the tectum.

Grover and Sharma ('81) reported similar retrogradely labeled neurons in two pretectal cell groups, area pretectalis and nucleus pretectalis, following tectal injections of HRP in goldfish. Area pretectalis and nucleus pretectalis in goldfish appear to be homologous to the central and periventricular pretectal nuclei in gars, based on similarities in topographical position and visual and tectal efferents (Sharma, '72; Northcutt and Butler, '76, '80; Grover and Sharma, '79). Comparison of these pretectal nuclei with those in other vertebrates is presently impossible due to the lack of detailed information on pretectal nuclei among different vertebrates.

It is noteworthy, however, that the superficial pretectal nucleus of gars-a nucleus that receives the heaviest retinal input of all pretectal nuclei-does not project to the tectum. Similar results are reported in goldfish (Grover and Sharma, '81), where the topographically indicated homologous nucleus is termed the lateral geniculate nu- 


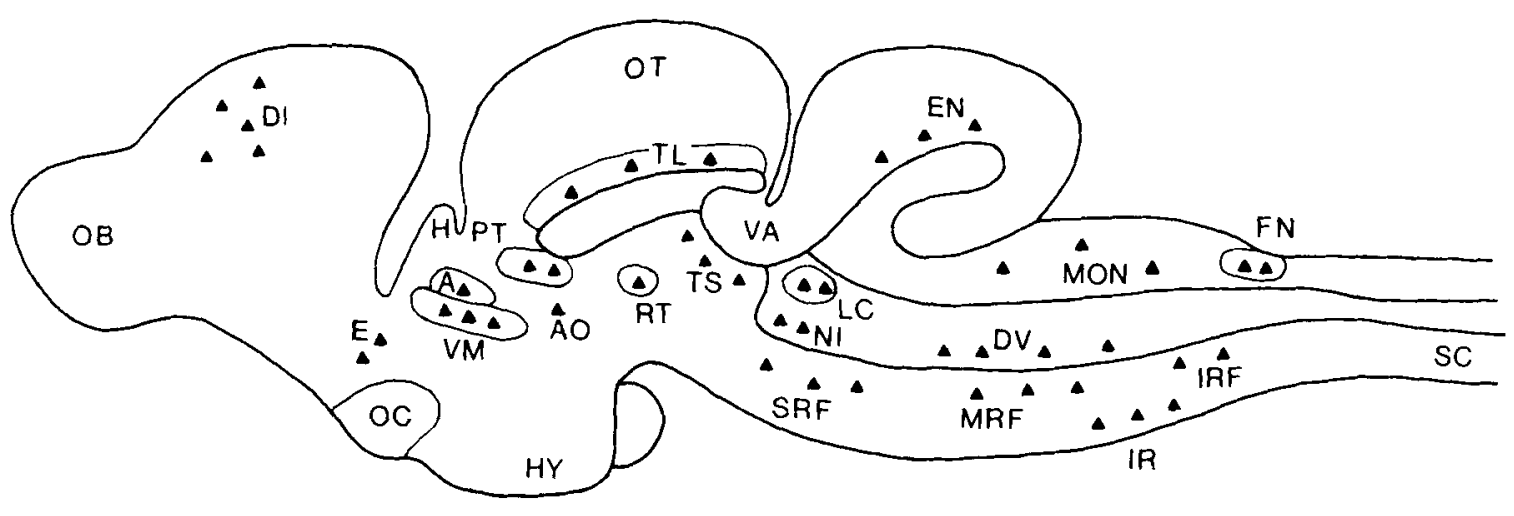

Fig. 7. Schematic midsagittal section through gar brain illustrating the relative position of nuclei whose cells (triangles) are retrogradely labeled following HRP injections into the optic tectum.

cleus. This nucleus is clearly misnamed in teleosts, as it does not project to either the tectum or the telencephalon. Lesions of the so-called lateral geniculate nucleus, or injections of tritiated proline - either of which would include nucleus rotundus - result in efferent projections to the ipsilateral valvula of the cerebellum and corpus mamillare (Northcutt and Braford, unpublished observations).

\section{Midbrain projections}

In gars, unilateral injections of HRP into the optic tectum result in large numbers of retrogradely labeled neurons ipsilaterally in the torus longitudinalis and bilaterally in the torus semicircularis (Figs. 3, 7). However, such injections label few neurons in the contralateral tectum (Fig. 3). There are labeled large pyriform cells in the periventricular gray zone, and an occasional fusiform cell in the central zone, but both types of labeled cells are surprisingly rare considering the extensive size of the tectal injections. A large number of labeled fibers exit the medial edge of the injection site in the tectum and cross the intertectal commissure; however, most of these fibers do not reach the lateral half of the contralateral tectum, and many of the fibers that do reach this site then exit the tectum and can be traced into the more ventrally situated torus semicircularis. Thus it seems likely that many, perhaps a majority, of these fibers are anterogradely labeled fibers that are terminating in the contralateral tectum and torus semicircularis. The origin of these fibers is uncertain. Although many of them may arise from cells in the injected tectum, they could also arise from the ipsilateral torus semicircularis and/or rostral tegmental nuclei. Grover and Sharma ('81) reported similar labeling of cells bilaterally in the torus semicircularis in goldfish and stated that HRP injections into the torus semicircularis label toral efferents that do pass through the intertectal commissure to terminate in the contralateral torus semicircularis. Clearly, data from other tracing methods whose interpretation is not compounded by axons of passage are needed to provide a more accurate picture of toral and tectal interconnections.

The rostral tegmental and accessory optic nuclei are the only tegmental nuclei that appear to project to the optic tectum in gars (Figs. 3B, 7). Both projections are almost totally ipsilateral, but occasionally well-filled cells were seen in the contralateral rostral tegmental nucleus (Fig. $3 B)$. These cells may project to the tectum, but, again, the labeling could be due to fibers interrupted in passage through the tectum. In goldfish, Grover and Sharma ('81) reported a similarly labeled nucleus which they termed the nucleus of the rostral mesencephalic tegmentum. These mesencephalic nuclei in gars and goldfish also receive tectal input (Grover and Sharma, '79, Northcutt and Butler, ' 80 ). At present there are insufficient data to identify the homologues of these nuclei in other vertebrates. Sheldon ('12) suggested that these nuclei were homologous to nucleus ruber, but Grover and Sharma ('81) questioned this homology on the basis of their failure to find cerebellar efferents to their nucleus of the rostral mesencephalic teg. mentum following HRP injections into the cerebellum.

A poorly defined cluster of neurons embedded among the descending tectobulbar fibers in gars (Fig. 3C) is probably the homologue of nucleus isthmi in other vertebrates. This cell group receives tectal efferents (Northcutt and Butler, '80) and retrogradely labeled cells are seen following tectal injections. An isthmotectal projection was reported for a similarly located nucleus in goldfish (nucleus isthmi, Grover and Sharma, '81); however, an earlier study failed to report tectal projections to this nucleus (Grover and Sharma, '79).

\section{Cerebellar projections}

Although earlier claims of direct tectocerebellar pathways in fishes (Ariëns Kappers et al., '36) have not been experimentally substantiated (Karten and Finger, '76; Finger, '78a,b; Grover and Sharma, '79; Northcutt and Butler, '80), extensive pathways from the cerebellum to the tectum do exist. Eurydendroid cells of the cerebellum are retrogradely labeled following tectal injections in gars (Figs. 4B, 7). Similar projections have been demonstrated in catfish (Finger, '78a) and are also seen in gars following injections of tritiated proline into the corpus of the cerebellum (unpublished observations). Crossed cerebellar projections also occur to the ventromedial thalamic nucleus (Braford and Northcutt, ' 81 ), many of whose cells project to the optic tectum (Fig. 2B), as demonstrated in this study. Ito and Kishida ('78) were the first to report a third cerebellotectal pathway in fishes. These workers demonstrated that the valvula of the cerebellum projects to the torus longitudinalis which, in turn, projects to the optic tectum to form the bulk of its superficially located marginal fiber layer. Similar toral projections to the tectum are reported in goldfish (Grover and Sharma, '81) and 
are demonstrated here in gars. Thus, although valvular projections to the torus have not yet been demonstrated in gars, projections of the torus to the tectum strongly suggest that a similar pathway exists.

\section{Brainstem projections}

This study has revealed afferent projections to the tectum from the following brainstem nuclei: ipsilaterally from the inferior raphe; bilaterally from the locus coeruleus, superior, medial, and inferior reticular formations, and the nucleus of the descending trigeminal tract; and contralaterally from the medial octavolateralis nucleus and the dorsal funicular nucleus. Grover and Sharma ('81) reported retrogradely labeled neurons only in the ipsilateral superior reticular formation following tectal injections of HRP in goldfish. However, they did not utilize tetramethylbenzidine as a substrate in their HRP reactions and noted that their subsequent experience with this chromagen indicated its greater sensitivity.

In addition, several of the data reported here for gars are also substantiated in other vertebrates. Knudsen ('77) and Boord and Northcutt ('79) reported direct projections to the tectum in catfish and skates, respectively, from the medial octavolateralis nucleus following lesions of this nucleus or injections of tritiated proline. Wallenberg ('07) reported experimentally determined projections to the tectum from the nucleus of the descending trigeminal tract in sharks; Molenaar and Fizaan-Oostveen ('80) reported similar projections in pythons. Other projections reported in gars-tectal projections from locus coeruleus, inferior raphe, medial and inferior reticular formations, and the dorsal funicular nucleus -await further experimental studies to establish the extent of their existence among other vertebrates.

\section{ACKNOWLEDGMENTS}

I thank Dr. Mark R. Braford, Jr., for participating in the preliminary stages of this study, and Mr. Harry Sloan for his energy and expertise as a technologist in my laboratory. Mary Sue Northcutt also assisted in many phases of the research and preparation of the manuscript. This work was supported by NIH grant EY02485.

\section{LITERATURE CITED}

Ariëns Kappers, C.U., G.C. Huber, and E.C. Crosby (1936) The Comparative Anatomy of the Nervous System of Vertebrates, Including Man. Reprinted 1960. New York: Hafner Publishing Company.

Bass, A.H. (1979) Telencephalic Afferents and Efferents in the Channel Catfish, Ictalurus punctatus. Doctoral Dissertation, University of Michigan, $214 \mathrm{pp}$.

Bodznick, D., and R.G. Northcutt (1980) Segregation of electro- and mechanoreceptive inputs to the elasmobranch medulla. Brain Res. 195:313-321.

Boord, R.L., and R.G. Northcutt (1979) Ascending projections of anterior and posterior lateral line lobes of the clearnose skate, Raja eglanteria. Anat. Rec. 193:487-488.

Braford, M.R., Jr., and R.G. Northcutt (1981) Organization of the diencephalon and pretectum in ray-finned fishes. In R.E. Davis and R.G. Northcutt (eds): Fish Neurobiology. Vol. II. Ann Arbor: University of Michigan Press, in press.

Coleman, D.R., F. Scalia, and E. Cabrales (1976) Light and electron microscopic observations on the anterograde transport of horseradish peroxidase in the optic pathway in the mouse and rat. Brain Res. 102:156-163.

Crossland, W.J., and C.J. Uchwat (1979) Topographic projections of the retina and optic tectum upon the ventral lateral geniculate nucleus in the chick. J. Comp. Neurol. 185:87-106.

Echteler, S.M., and W.M. Saidel (1981) Forebrain connections in the gold- fish support telencephalic homologies with land vertebrates. Science 212:683-685.

Finger, T.E. (1978a) Efferent neurons of the teleost cerebellum. Brain Res. 153:608-614

Finger, T.E. (1978b) Cerebellar afferents in teleost catfish (Ictaluridae). J. Comp. Neurol. 181:173-182.

Fite, K.V., R.G. Carey, and D. Vicario (1977) Visual neurons in frog anterior thalamus. Brain Res. 127:283-290.

Grofová, I., O.P. Ottersen, and E. Rinvik (1978) Mesencephalic and diencephalic afferents to the superior colliculus and periaqueductal gray substance demonstrated by retrograde axonal transport of horseradish peroxidase in the cat. Brain Res. 146:205-220.

Grover, B.G., and S.C. Sharma (1979) Tectal projections in the goldfish (Carassius auratus): A degeneration study. J. Comp. Neurol. $184: 435-454$.

Grover, B.G., and S.C. Sharma (1981) Organization of extrinsic tectal connections in goldfish (Carassius auratus.) J. Comp. Neurol. 196:471-488.

Gruberg, E.R., E. Kicliter, E.A. Newman, L. Kass, and P.H. Hartline (1979) Connections of the tectum of the rattlesnake (Crotalus viridis): an HRP study. J. Comp. Neurol. 188:31-42.

Ito, H, and R. Kishida (1977) Tectal afferent neurons identified by the retrograde HRP method in the carp telencephalon. Brain Res. 130:142-145.

Ito, H., and R. Kishida (1978) Telencephalic afferent neurons identified by the retrograde HRP method in the carp diencephalon. Brain Res. 149:211-215.

Karten, H.J., and T.E. Finger (1976) A direct thalamo-cerebellar pathway in pigeon and catfish. Brain Res. 102:335-338.

Knudsen, E.I. (1977) Distinct auditory and lateral line nuclei in the midbrain of catfishes. J. Comp. Neurol. 173:417-432.

McCormick, C.A. (1978) Central Projections of the Lateral Line and Eighth Nerves in the Bowfin, Amia calva. Doctoral Dissertation, University of Michigan, $131 \mathrm{pp}$.

McCormick, C.A. (1981) Central projections of the lateral line and eighth nerves in the bowfin, Amia calva. J. Comp. Neurol 197:1-16.

Mesulam, M.-M. (1979) A tetramethyl benzidine method for the light microscopic tracing of neural connections with horseradish peroxidase (HRP) histochemistry. In: Neuroanatomical Techniques. Society for Neuroscience, Bethesda, Maryland, pp. 65-71.

Molenaar, G.J., and J.L.F.P. Fizaan-Oostveen (1980) Ascending projections from the lateral descending and common sensory trigeminal nuclei in Python. J. Comp. Neurol. 189:555-572.

Neary, T.J., and W. Wilczynski (1980) Descending inputs to the optic tectum in ranid frogs. Soc. Neurosci. Abstr. 6:629.

Northcutt, R.G. (1981) Localization of neurons afferent to the telencephalon in a primitive bony fish, Polypterus palmas. Neurosci. Lett. 22:219-222.

Northcutt, R.G., and M.R. Braford, Jr. (1980) New observations on the organization and evolution of the telencephalon of actinopterygian fishes. In S.O.E. Ebbesson (ed): Comparative Neurology of the Telencephalon. New York: Plenum, pp 41-98.

Northcutt, R.G., and A.B. Butler (1976) Retinofugal pathways in the Iongnose gar Lepisosteus osseus (Linnaeus). J. Comp. Neurol. 166:1-16.

Northcutt, R.G., and A.B. Butler (1980) Projections of the optic tectum in the longnose gar, Lepisosteus osseus. Brain Res. 190:333-346.

Parent, A., and R.G. Northcutt (1981) The monoamine-containing neurons in the brain of the garfish, Lepisosteus osseus. Brain Res. Bull. (in press).

Ronan, M.C., and R.G. Northcutt (1979) Afferent and efferent connections of the bullfrog medial pallium. Soc. Neurosci. Abstr. 5:146.

Scalia, F., and K. Gregory (1970) Retinofugal projections in the frog: Location of the postsynaptic neurons. Brain Behav. Evol. 3:16-29.

Schnitzlein, H.N. (1962) The habenula and dorsal thalamus of some teleosts. J. Comp. Neurol 118:225-268.

Sharma, S.C. (1972) The retinal projections in the goldfish: An experimental study. Brain Res. 39:213-223.

Sheldon, R.E. (1912) The olfactory tracts and centers in teleosts. J. Comp. Neurol. 22:177-340.

Trachtenberg, M.C., and D. Ingle (1974) Thalamo-tectal projections in the frog. Brain Res. 79:419-430.

Wallenberg, A. (1907) Bejträge zur Kenntnis des Gehirns der Teleostier und Selachien. Anat. Anz. 31:369-399.

Wilczynski, W. (1978) Connections of the Midbrain Auditory Center in the Bullfrog, Rana catesbeiana. Doctoral Dissertation, University of Michigan, $196 \mathrm{pp}$. 